\title{
The Current College Educational Management Status and Innovation Mechanism in the New Situation
}

\author{
Zhi Cao \\ Nanchang Hang kong University of Art \& Design Academy, China
}

Keywords: College education; Teaching management; Reform measures; Strategy exploration

\begin{abstract}
Modern educational reform aims to promote the students' overall development and improve their comprehensive quality. At present, college educational management reform has also become the focus of the whole society and requires deep research by the education authorities involved. In recent years, the running scale of our colleges is constantly enlarging and the teaching concepts are upgrading, however, the old teaching modes are also showing in the increasingly diversified forms. As the reform goes deeper, many new teaching forms and tasks have been applied in the practical educational management of colleges, and proved more suitable for the daily teaching management of colleges. However, in terms of current college educational management, there remain more or less some problems. Most of the colleges are still harboring the stale thoughts and concepts, paying inadequate attention to teaching management, therefore, the management staff usually slack off in their position and lack the basic innovative thoughts.
\end{abstract}

\section{Introduction}

Since the access into WTO, we have achieved a rapid development in our economy and the educational industry has also seen the favorable boom of development on the back of the educational reform policies in the new situation. It is the time for our colleges to ponder how to arrange the reforms to suit the current teaching management work. Besides the strict internal management, it is also necessary to strengthen educational teaching management reform. The reform can stabilize the college management mechanism at certain extent, improve their teaching quality and cultivate more talents. Grip the control over the educational management requires strengthening the control over the whole college and make the daily work more scientific and reasonable. However, according to data, we still have a long way to go in college educational management, since at different levels there are problems in different depth which may affect the sustainable development of the colleges from micro perspectives and the modern educational reform progress from the macro perspectives. Therefore, it is the top priority of the colleges to find out the issues in college educational management reforms by means of real cases, and this is also the movement that deserves deep consideration of mass educators.

\section{The Scientific Essence of College Educational Management Mechanism Innovation}

Possible to Improve the Competitiveness of the Colleges. Literally, college educational management mechanism innovative reform starts from the inside and helps the colleges meet their teaching management objective. However, this general version cannot be counted as a definition, because its real connotation is a kind of mutually restrained organization form and duty division system through reform or innovation in teaching management activities in face of domestic or international competition. We ever made an early exploration about the college educational management mechanism innovation, aiming to improve the colleges' competitiveness and cultivate innovative talents for our country. College educational management mechanism is an important part of modern educational reform and shall combine with the current advanced college teaching management concepts. We shall keep its validity and truth in the process of construction, and prevent the practice of formalization.

Educational Management System Innovative Development Is the Inevitable Choice of Colleges. College educational management mechanism has been advocated in our country. It not 
only corresponds to the requirement of modern educational reform, and also conforms to the development tide of the current times. In recent years, the teaching modes in our colleges have basically changed. With the student scale enlarges, the college education has turned to mass education; therefore, the innovation and reform on the educational management mechanism at current stage is the natural choice of the colleges. The traditional educational management mechanism shall be innovated to find the suitable educational management methods and get the management resources allocated at the best efficiency.

Possible to Improve College Teaching Quality. As our country is paying more and more attention to college education and increasing more educational fund, college educational management mechanism has been accepted by most of the enterprises, and over time the number of college graduates is also gradually increasing, but the society is not giving back the optimistic information on their innovation and practice capacity. Some college students lack the basic work abilities, have low comprehensive quality and sense of responsibility, only thinking of their own interests. The purpose of college education shall be to cultivate compressive and innovative talents to the society; therefore, it is the top priority of the colleges to deepen educational management reform and improve educational management mechanism. Innovative talents are the most precious wealth of our nation, and the colleges are the important base for talent cultivation. Deepening reform the college educational management mechanism is a rigorous challenge that we must face in the new era. It is the objective requirement of social development, the necessary condition for the survival of colleges, and also the effective channels of improving college teaching quality.

\section{The Problems in Current College Educational Management}

With the implementation of college educational reform, the function of educational management is becoming more obvious. It can make sure the smooth going of college management, serve a great function in internal management, and has gradually become the criterion of judging college management level. However, we also have to emphasize the problems revealed in the process of innovation and reform:

Ignorance of the Educational Management Staff. As college educational management system remains unsound, many people have little understanding of the theories, especially some leaders of educational authority. Therefore, without a standard educational management system, they tend to handle the matters with their experience and inevitably have something left out. Another outstanding problem is the perfunctory performance of the management staff, even though there are prescribed regulations. They can function very little when they make fashion at the time of inspection. Besides the leaders, many of the staff just know educational management from the literal sense and merely go through formalities in the work, which will inevitably bring harm to the sustainable development of the colleges and the students. Lack of a high compressive quality and faith is also widespread among the educational management staff, as a result, they show quite uneven abilities in addressing the matters. In their daily work, they just hope for no mistakes but never think to achieve something. In summary, the management staff is commonly short of innovative spirit and enthusiasm in the process of educational management.

The Imperfect Educational Management System. In some colleges, the educational management may meet some obstacles in aspects of environment, capital and labor or from the ignorance of the educational management workers, as a result, they have to face a fragile educational management system, even though it is established, the educational management work will be stuck in formalization and hard to ensure its scientific rationality. The objective of modern education management is to innovate on the traditional teaching system and form a new set of educational management system. However, for most of the colleges, the management system is just nothing but an empty policy. Living in the era of information, we are required to grasp a strong ability in information collection and utility, and these abilities have been the weak points of the colleges. What's the most important is the dislocation between the current educational management system in colleges and the times, making it unable to meet the requirement of current social development. The college educational management workers still hold backward educational 
management concepts as used in the past administrative management, and fail to adjust the structure of the internal faculty in time. Besides, they also use the traditional educational management mode to limit the behaviors of the teachers and students, and ignore people-oriented principle. That has not only damaged the enthusiasm of the teachers and students for creation, and also harmful for the innovative reform of college educational management.

Inadequate Supervision over Educational Management Work. The control over educational management is closely linked with the power of supervision. In case of an inadequate control, there tends to be a fragile supervision system and the behaviors departing from the educational management norm, leaving the educational management system an empty rule. That's because the internal managers may hold a conflict psychology to the education al management system, and cannot work hard in their work. Some colleges may put too much emphasis on development but very little on management, leading to many management problems when many teachers cannot see any restraints on their behaviors. The responsibility system cannot be well implemented and the educational managers do not have a sense of participation. Consequently, the responsible persons cannot be found when some problems emerge. The most serious is the unsound teaching quality evaluation system. In many colleges, the evaluation is only conducted by standard of a lecture, so the teachers can get an excellent evaluation result with good preparations in advance. In summary, it is the educational management system that has limited many rights of the management workers and got the management system a surface rule.

Improper Arrangement of Teaching Tasks in Colleges. In our country, college educational management modes are generally in the form of grading system, and only the leaders have the power for decision. However, the development theme in current times is built on the economic interests, and the pressure from the society is also hindering the establishment of college educational management system. The college managers would usually reduce the expenditure and save teaching faculty resources to achieve the rapid development of their colleges, getting many courses impossible to finish. Some only emphasize skill training but ignore the cultivation of management talents, only trying to strengthen faculty team construction and professional skill training. The colleges think the practical talents are the basis for the survival and development of the country; however the managers can only pay lip service, and most of the courses they set are already out of date; the teachers only give rough lectures under the pressure from college teaching task, getting the students out of the interest in study and dragging the teaching progress. Nevertheless, many of the colleges still follow the traditional exam-oriented teaching mode. while the exam scores measure the students' study result, it also weakens their independent thinking ability and forms the concept of using exam score as the only criterion for the student's study result, which hinders the diversified development of the students at certain extent.

\section{Innovative Development and Strategy Exploration of College Educational Management Mechanism in New Situation}

Improve the Sense of Responsibility of the Management Staff. Improving the sense of responsibility of the college educational management staff and the responsible persons can fundamentally realize the innovative development of educational management mechanism. First, the managers shall fully realize the importance of educational management for the sustainable development of the colleges and learn the related management concepts; then educational management system shall be worked out based on the actual conditions of the colleges and keep improving; lastly, make regular publicity and education of educational management among the staff to form a positive work atmosphere and get the specific duties implemented. Improve the comprehensive quality of the educational management staff, enhance their professional quality, learn how to handle the problems repeatedly appear in their work, and grasp the corresponding work procedure and level. Then what comes is the education in terms of professional ethics. The management works shall abide by college system and national law, prevent corruption; and the colleges shall separate the irrelevant positions based on their actual conditions and make sure the education work more fair and balanced. 
Innovate Educational Management Mechanism. College educational management mechanism includes management system, staff arrangement and management analysis. Its establishment and improvement requires the mutual restraint and supplement between the colleges. The educational management tasks and responsibility division worked out under this premise can get all the information sent out at the best efficiency. College manager shall innovate educational management mechanism, work hard to serve all the teachers and students. Complement people-oriented concept in educational management, strengthen campus cultural construction to promote the vigorous development of colleges.

Strengthen the Supervision of the Educational Management. A proper evaluation system shall be set up in colleges to standardize all the work. Specifically, strengthen internal and external audit to further standardize the behaviors of all the teachers, a supervision system can be established to make sure the teachers organize teaching as arranged by the colleges. The corresponding reward and punishment system shall be set up to prevent the illegal behaviors of the management staff or the behaviors damaging the interests of the colleges, such as corruption and public fund embezzlement, and at the same time praise the excellent managers and teacher to stimulate the work enthusiasm. In this way can make sure the stability of college internal education management and realize the educational management objective.

Reasonable Arrangement of Teaching Tasks. With the constant innovation in college educational management, the colleges must make reasonable arrangement of teaching tasks to achieve stable development. First, the management in the colleges shall realize the importance of teaching quality for the development of the students and colleges, never try to save a little but spoil the future of the students. then, the educational managers shall conduct deep surveys to understand the class status of the teachers and students, and strengthen teacher faculty construction, emphasize the diversified development of the students, respect and maintain their independent ideas in different fields, since each of them are independent individuals.

\section{Conclusion}

In the current situation of domestic educational reform, college educational management mechanism innovation has been extremely urgent. We shall fulfill our duties in light of the internal problems of colleges, change the previous educational management concepts and establish a correspondingly perfect educational management mechanism to fundamentally improve the management levels of colleges, make sure the stable development of colleges and national educational cause.

\section{References}

[1] Wang Min, The Current Status and Innovation Mechanism of College Educational Management in the New Situation [J], Lanzhou Institute of Education Journal, 2013,01:92-93.

[2] Chen Minglu, The Current Status and Innovation Mechanism of College Educational Management in the New Situation [J], Science \& Technology Information, 2013,16:176.

[3] Mo Liping, The Practical Plight and Innovative Path of College Educational Management in the New Situation [J], Chinese Worker Education, 2014,24:118.

[4] Song Lei, The Current Status and Innovation Mechanism of College Educational Management in the New Situation [J], Management informationization of China, 2015,04:251.

[5] Ren Ronghua, The Current Status and Innovation Mechanism of College Educational Management in the New Situation [J], Contemporary Education Practice and Teaching Research, 2015:83.

[6] Yuan Yamin, The Current Status of College Educational Management and Innovative Mechanism Research in the current Situation [J], Time Education, 2014,15:108-109. 
[7] Wang Xin, College Ideological and Political Education Mechanism Innovative Research [D], Shanxi University, 2011 